\title{
Przemysław Panfil
}

Uniwersytet Gdański, Wydział Prawa i Administracji

e-mail: ppanfil@prawo.ug.edu.pl

\section{OGRANICZENIE DZIAŁALNOŚCI SĘPICH FUNDUSZY} W STREFIE EURO - WNIOSKI DE LEGE LATA

\section{DE LEGE FERENDA}

\section{LIMITING THE ACTIVITIES OF VULTURE FUNDS IN THE EUROZONE - DE LEGE LATA AND DE LEGE FERENDA CONCLUSIONS}

DOI: $10.15611 / \mathrm{pn} .2018 .531 .31$

JEL Classification: K33, K41, G18

Streszczenie: W ostatnich latach w porządku prawnym Unii Europejskiej pojawiło się wiele rozwiązań, które mają przyczynić się do rozwiązywania potencjalnych kryzysów zadłużeniowych w strefie euro. Jednym z kluczowych elementów nowo tworzonego systemu przywracania stabilności fiskalnej państw członkowskich jest proces restrukturyzacji zadłużenia oparty na wykorzystaniu klauzul wspólnego działania. Zagrożeniem dla skuteczności tego procesu jest działalność sępich funduszy, która uzasadnia interwencję unijnego prawodawcy. Artykuł ma dwa równorzędne cele. Pierwszym z nich jest wskazanie przesłanek wprowadzenia do porządku prawnego Unii Europejskiej rozwiązań, które ograniczałyby działalność sępich funduszy na rynku długu publicznego państw członkowskich strefy euro. Drugim celem jest natomiast określenie założeń leżących u podstaw tego typu regulacji. W trakcie pracy nad artykułem posłużono się analizą dogmatyczną oraz prawnoporównawczą.

Slowa kluczowe: dług publiczny, skarbowe papiery wartościowe, restrukturyzacja zadłużenia, klauzule wspólnego działania, sępie fundusze.

Summary: In recent years, many solutions have emerged in the legal order of the European Union that are to contribute to solving potential debt crises in the Euro area. One of the key elements of the newly created system intended for restoring fiscal stability of Member States is the process of debt restructuring based on the use of joint action clauses. The threat to the effectiveness of this process is the activity of the vulture funds which justifies the intervention of the EU legislator. The article has two equal goals. The first one is the indication of the reasons for introducing into the legal order of the European Union solutions that would limit the activities of vulture funds on the public debt market of Member States included in the Eurozone. The second aim is to define the assumptions underlying this type of regulation. While working on the article, a dogmatic and legal-comparative analysis was used.

Keywords: public debt, tresury securities, debt restructuring, collective action clauses, vulture funds. 


\section{Wstęp}

Truizmem jest twierdzenie, że Unia Europejska (dalej jako: UE) była instytucjonalnie nieprzygotowana na kryzys zadłużeniowy, który rozpoczął się na przełomie 2009 i 2010 r. W szczególności brakowało rozwiązań, które umożliwiałyby szybkie udzielenie pomocy państwom mającym problemy z rynkowym finansowaniem potrzeb pożyczkowych. Rosnące ryzyko niekontrolowanego bankructwa niektórych członków strefy euro stało się przy tym poważnym wyzwaniem dla procesu integracji monetarnej w Europie. W tym kontekście kryzys zadłużeniowy stał się katalizatorem zmian porządku prawnego UE. Ich celem było zwiększenie skuteczności systemu ochrony stabilności fiskalnej państw członkowskich, jak i stworzenie mechanizmu jej przywracania. Mimo dotychczasowego wysiłku unijnego prawodawcy proces zmian legislacyjnych zainicjowany przez rozwój zjawisk kryzysowych trudno uznać za zakończony. Nadal istnieje wiele rozwiązań wymagających modyfikacji, jak i obszarów, które nie zostały dotychczas uregulowane. Jednym $\mathrm{z}$ nich jest działalność tzw. sępich funduszy (ang. vulture funds). Stanowi ona poważne wyzwanie dla procesu restrukturyzacji długu publicznego w krajach, które utraciły stabilność fiskalną.

Artykuł ma dwa równorzędne cele. Pierwszym z nich jest wskazanie przesłanek wprowadzenia do porządku prawnego UE rozwiązań, które ograniczałyby działalność sępich funduszy na rynku długu publicznego państw członkowskich strefy euro. Drugim celem jest natomiast określenie założeń leżących u podstaw tego typu regulacji. W trakcie pracy nad artykułem posłużono się analizą dogmatyczną oraz prawnoporównawczą. Odniesiono się także do obowiązującego materiału normatywnego, źródeł wtórnych w literaturze przedmiotu oraz raportów opracowanych przez Międzynarodowy Fundusz Walutowy.

Badania zostały sfinansowane $\mathrm{z}$ grantu naukowego przyznanego przez Narodowe Centrum Nauki pt. Iluzje fiskalne w Polsce (numer decyzji: DEC-2015/19/D/ HS5/03317).

\section{Restrukturyzacja zadłużenia publicznego}

Państwo, które trwale traci zdolność do wywiązywania się z zaciągniętych zobowiązań, staje przed koniecznością dokonania restrukturyzacji swojego zadłużenia. Pojęcie to można zdefiniować jako wymianę dotychczasowych instrumentów dłużnych na nowe instrumenty lub gotówkę w drodze procesu prawnego [Das, Papaioannou, Trebesch 2012]. Proces ten może opierać się na redukcji wartości nominalnej zaciągniętych zobowiązań i/lub zmianie harmonogramu świadczeń przysługujących wierzycielom oraz oprocentowania instrumentów dłużnych.

$\mathrm{Z}$ samej swojej istoty restrukturyzacja zadłużenia jest procesem niezmiernie złożonym. Do końca lat 80 . pewnym ułatwieniem dla władz publicznych był jednak wysoki stopień koncentracji struktury długu Skarbu Państwa, w której kluczową 
rolę odgrywały kredyty bankowe. Negocjacje w sprawie restrukturyzacji zadłużenia prowadzono więc z dość wąską, jednolitą i niejednokrotnie powiązaną ze sobą kapitałowo grupą wierzycieli [Marki i in. 2012]. Sytuacja ta uległa daleko idącej zmianie w związku z masowym wykorzystaniem skarbowych papierów wartościowych. W konsekwencji doszło do istotnego rozproszenia podmiotowej struktury zadłużenia współczesnych państw. Przykładowo po bankructwie Argentyny w 2001 r. grono jej wierzycieli liczyło około 600 tys. podmiotów [Das i in. 2012]. Taki stan rzeczy uniemożliwia de facto oparcie procesu restrukturyzacji zadłużenia na indywidualnych negocjacjach z pożyczkodawcami.

Odpowiedzią na powyższe wyzwania stają się tzw. klauzule wspólnego działania (ang. Collectiva Action Clauses; dalej jako: CACs). Jest to zbiór postanowień kontraktowych, które upraszczają proces restrukturyzacji długu. Ich wykorzystanie można przy tym uznać za formę uporządkowanego bankructwa państwa. W praktyce można doszukać się różnych modeli CACs. Wśród nich kluczowe znaczenie należy przypisać tzw. klauzulom wspólnej zamiany. Pozwalają one grupie obligatariuszy, posiadających skarbowe papiery wartościowe o określonej wartości, zaakceptować propozycje restrukturyzacji w sposób wiążący wszystkich wierzycieli. Zasady modyfikacji kontraktów emisyjnych bywają przy tym różnicowane w zależności od takich czynników, jak charakter zmienianych postanowień kontraktowych, liczba modyfikowanych serii rządowych papierów dłużnych czy też tryb zatwierdzania nowych warunków przez obligatariuszy [Mosionek-Schweda, Panfil 2014].

Dobrym przykładem CACs są rozwiązania przyjęte w państwach strefy euro z dniem 1 stycznia 2013 r. na podstawie art. 12 ust. 4 Traktatu ustanawiającego Europejski Mechanizm Stabilności [Traktat z 2 lutego 2012] ${ }^{1}$. Dzielą one postanowienia kontraktowe na „sprawy zastrzeżone”, wymienione w enumeratywnym katalogu, oraz „sprawy niezastrzeżone” (wszystkie postanowienia, które nie są zaliczane do „spraw zastrzeżonych”). Do tych pierwszych zalicza się między innymi: redukcję płatności należnych obligatariuszom, odroczenie terminu płatności, a także zmianę waluty i miejsca płatności. Tym samym ,sprawy zastrzeżone” to postanowienia kontraktowe mające kluczowe znaczenie z punktu widzenia procesu restrukturyzacji zadłużenia. Modyfikacja postanowień kontraktowych w tym zakresie dokonywana w formie głosowania wymaga poparcia co najmniej 3/4 wartości nominalnej zaległych instrumentów należących do obligatariuszy reprezentowanych na spotkaniu, przy kworum wynoszącym $2 / 3$ wartości tych instrumentów. Natomiast jeżeli procedura jest przeprowadzana w sposób pisemny, próg poparcia wynosi co najmniej $2 / 3$. W modyfikacji pojedynczej powyższe wielkości odnoszą się do wartości instrumentów jednej serii, zaś w modyfikacji krzyżowej - wartości instrumentów wszystkich serii. W tym ostatnim wypadku pojawiają się jednak dodatkowe wymogi. Warunkiem zatwierdzenia postanowień kontraktowych w drodze modyfikacji krzyżowej jest bowiem uzyskanie odpowiedniego progu poparcia obligatariuszy

1 Przyjęty w strefie euro model CACs jest dostępny na stronie internetowej Komitetu Ekonomiczno-Finansowego Unii Europejskiej: https://europa.eu/efc/euro-area-model-cac-2012_en. 
każdej serii obligacji objętej tą modyfikacją. Jeżeli procedura przeprowadzana jest w drodze głosowania, próg ten wynosi $2 / 3$ wartości instrumentów pojedynczej serii należących do wierzycieli reprezentowanych na spotkaniu. W przypadku głosowania pisemnego poparcie dla zmiany postanowień kontraktowych musi natomiast wynieść co najmniej 50\%. Tym samym stosunkowo nieliczna grupa obligatariuszy posiadających duży udział w pojedynczej serii skarbowych papierów wartościowych może zablokować modyfikację krzyżową. Co więcej, specjalnie w tym celu mogą oni kupować na rynku wtórnym tego typu instrumenty, korzystając $\mathrm{z}$ ich niskiej wartości [Deutsche Bundesbank 2016].

\section{Działalność sępich funduszy}

Sępie fundusze pojawiają się na rynku wtórnym skarbowych papierów wartościowych państw przeżywających poważne trudności fiskalne, skupując wyemitowane przez nie instrumenty z dużym dyskontem od wartości nominalnej. Następnie, odrzucając propozycje restrukturyzacji, żądają wypłaty wartości nominalnej nabytych papierów powiększonej o zapadłe odsetki. Tego typu strategia działania obarczona jest wysokim ryzykiem. Problematyczne jest zarówno uzyskanie korzystnego wyroku sądu, jak i jego późniejsza egzekucja. W związku z tym na taki profil działalności decyduje się stosunkowo wąska grupa wyspecjalizowanych podmiotów [IMF 2012], funkcjonujących zazwyczaj w formie funduszy hedgingowych (np. Elliott Associates, NML Capital Ltd.). Potencjalnie sępie fundusze mogą jednak osiągnąć spektakularny zysk. Dobrze pokazuje to chociażby przykład Argentyny, która zbankrutowała w $2001 \mathrm{r}$. W efekcie tego wydarzenia w połowie $2002 \mathrm{r}$. obligacje wyemitowane przez ten kraj osiągnęły na rynku wtórnym cenę wynoszącą jedynie $20 \%$ ich wartości nominalnej. Stały się przy tym przedmiotem zainteresowania sępich funduszy. W 2005 i 2010 r. Argentyna skierowała do swoich wierzycieli propozycje restrukturyzacji, którymi ostatecznie objęto $93 \%$ jej zadłużenia zewnętrznego [IMF 2014]. Tymczasem sępie fundusze wytoczyły temu krajowi pozwy przed amerykańskimi i brytyjskimi sądami, domagając się wypłaty całości świadczeń wynikających z posiadanych instrumentów dłużnych.

Z punktu widzenia działalności sępich funduszy kluczowe znaczenia ma fakt, że na poziomie międzynarodowym nie ma prawa upadłościowego przeznaczonego dla państw. Tym samym związki publicznoprawne, które utraciły płynność lub są niewypłacalne, nie korzystają z żadnej formy dodatkowej ochrony prawnej. W konsekwencji typowy proces restrukturyzacji zadłużenia jest chaotyczny i pełen konfliktów. Tymczasem wspólnota może skutecznie rozwiązywać takie konflikty tylko wtedy, gdy organizuje się w sposób, który motywuje racjonalne wybory [Seavey 2006]. Pewnym krokiem w tym kierunku są niewątpliwie CACs. Niemniej nie są one w stanie zastąpić sądu upadłościowego, którego stworzenie jest postulowane w literaturze przedmiotu od czasu Adama Smitha [Blackman, Mukhi 2010]. Niestety wysiłki podejmowane w tym zakresie na arenie międzynarodowej nie 
przyniosły dotychczas wymiernych rezultatów. Umożliwia to sępim funduszom pozywanie związków publicznoprawnych przed sądami w innych państwach. Najczęściej są to kraje, w których doszło do emisji skarbowych papierów wartościowych. Większość takich emisji odbywa się w najważniejszych centrach finansowych, takich jak Nowy Jork lub Londyn. Niemniej zagraniczne emisje skarbowych papierów wartościowych plasuje się także w innych państwach. Dobrym przykładem są tutaj Niemcy, Luksemburg, Belgia czy też Włochy [Das i in. 2012].

Warunkiem sine qua non skutecznego dochodzenia roszczeń przez sępie fundusze jest przyjęcie przez sądy innego kraju wąskiej interpretacji immunitetu jurysdykcyjnego państwa. W prawie międzynarodowym publicznym przyjmuje się zwyczajowo, że żaden kraj nie może sądzić innego kraju. Przyjęcie szerokiej interpretacji tej zasady zamykałoby de facto sępim funduszom sądową drogę dochodzenia roszczeń. Wiele państw, w tym USA oraz Wielka Brytania, traktuje jednak immunitet jurysdykcyjny w sposób wąski, ograniczając go do sytuacji, w których obcy kraj działa z tytułu swej władzy (prawem władzy; łac. iure imperii). W tym ujęciu immunitet nie obowiązuje, kiedy państwo działa jako podmiot praw prywatnych (prawem zarządzania; łac. iure gestionis) [Góralczyk 2000]. W tym właśnie obszarze niewątpliwie mieści się proces zaciągania zobowiązań przez związek publicznoprawny.

Kolejnym istotnym problemem, jaki napotykają sępie fundusze, jest egzekucja uznanych przez sąd wierzytelności. Co do zasady współczesne państwa nie mają poza swoimi granicami majątku, z którego taka egzekucja byłaby możliwa. W tym zakresie skuteczne okazało się jednak wykorzystanie przez sępie fundusze klauzuli pari passu. Jest to standardowy element transgranicznych kontraktów emisyjnych. Zawiera on obietnicę pożyczkobiorcy do równego traktowania wszystkich płatności wynikających z niepodporządkowanego zadłużenia. Na międzynarodowym rynku finansowym klauzula pari passu była tradycyjnie rozumiana jako ochrona podobnie umocowanych pożyczkobiorców przed nierównym traktowaniem [Blackman, Mukhi 2010]. Sępie fundusze zaproponowały jednak dużo szerszą wykładnię tej klauzuli. Zgodnie z nią dane państwo nie może dokonać żadnych płatności na rzecz wierzycieli, którzy zgodzili się na restrukturyzację zadłużenia, bez jednoczesnego spełnienia świadczeń przysługujących wierzycielom, którzy odrzucili proponowane im warunki restrukturyzacyjne [Fish, Gentile 2004]. Co więcej, jedne i drugie należności powinny być realizowane w całości. Dobrym przykładem zastosowania powyższej taktyki mogą być działania Elliott Associates w trakcie sporu z Peru prowadzonego przed sądami belgijskimi. Interpretacja klauzuli pari passu zaproponowana przez sępi fundusz została ostateczne zaakceptowana przez Sąd Apelacyjny w Brukseli. W efekcie doszło do zablokowania płatności dokonywanych za pośrednictwem Euroclear na rzecz wierzycieli, którzy zgodzili się na restrukturyzację peruwiańskiego zadłużenia. W ten sposób rząd w Limie, chcąc uniknąć kolejnego bankructwa swojego kraju, został zmuszony do spełniania roszczeń sępiego funduszu. 


\section{Ograniczenie działalności sępich funduszy}

Istnieje kilka potencjalnych rozwiązań, które mogą uniemożliwić lub ograniczyć działalność sępich funduszy. Niewątpliwie najskuteczniejsze byłoby powołanie do życia międzynarodowego sądu upadłościowego, który mógłby działać chociażby pod auspicjami Międzynarodowego Funduszu Walutowego [Hilgers 2003]. Krok ten wymagałby jednak osiągnięcia szerokiego porozumienia, obejmującego nie tylko kraje UE, lecz także takie państwa, jak USA, Japonia i Szwajcaria. Brak tego porozumienia wymusza podjęcie działań na poziomie UE lub jedynie wewnątrz strefy euro. Uzasadnieniem dla tego ostatniego podejścia jest fakt, że jednolity model CACs funkcjonuje wyłącznie w państwach jednolitego obszaru walutowego.

Przeciwdziałanie sępim funduszom na poziomie strefy euro mogłoby polegać na przyjęciu jednolitego schematu kontraktów emisyjnych skarbowych papierów wartościowych oraz/lub zmianie kształtu modelu CACs [Seavey 2006]. W tym pierwszym wypadku szczególny nacisk należałoby położyć na zapisy dotyczące klauzuli pari passu. Nie powinny one pozostawiać wątpliwości, że możliwa jest jedynie jej wąska interpretacja. W ten sposób sępie fundusze utraciłyby możliwość blokowania wypłat dokonywanych na rzecz wierzycieli, którzy zostali objęci procesem restrukturyzacji zadłużenia. Nowelizacja modelu CACs powinna natomiast polegać na zmianie zapisów dotyczących modyfikacji krzyżowych. Proces restrukturyzacji należy uzależnić wyłącznie od uzyskania założonego progu poparcia obligatariuszy wszystkich serii papierów objętych tą modyfikacją, rezygnując z dodatkowej konieczności rozpatrywania tego poparcia na poziomie pojedynczej serii. W ten sposób sępie fundusze, posiadające wysokie udziały w krótkich seriach skarbowych papierów wartościowych, utraciłyby możliwość blokowania restrukturyzacji. Co więcej, wzrosłaby szansa na narzucenie im warunków restrukturyzacyjnych w zgodzie z kontraktem emisyjnym. Powyższe rozwiązania mają jednak poważną wadę. Można je wprowadzić wyłącznie w odniesieniu do nowo emitowanych serii skarbowych papierów wartościowych. Papiery starych serii, czasami o kilkudziesięcioletnich terminach zapadalności, nadal podlegałyby starym zasadom. Znacząco komplikowałoby to proces ewentualnej restrukturyzacji zadłużenia w krótkoi średnioterminowej perspektywie.

W kontekście przedstawionych problemów we wdrażaniu alternatywnych rozwiązań wydaje się, że najlepszym sposobem powstrzymania działalności sępich funduszy w strefie euro jest interwencja unijnego prawodawcy. Warto podkreślić, że w ostatnich latach regulował on już różne zagadnienia mające istotne znaczenie dla funkcjonowania rynku długu państw członkowskich. Przykładem mogą być tutaj przepisy odnoszące się do działalności agencji ratingowych czy też możliwości wykorzystania tzw. nagich CDS-ów (ang. credit default swap). Ciekawym wzorcem dla unijnego prawodawcy może być przy tym belgijska ustawa z dnia 12 lipca $2015 \mathrm{r}$. w sprawie walki z działalnością sępich funduszy [De loi de 12 juillet 2015]. Belgia jest jednym z niewielu państw na świecie, które podjęły próbę ograniczenia działalności tego typu podmiotów. Kluczowym elementem belgijskich rozwiązań jest 
tzw. przesłanka nieuzasadnionej korzyści (fr. avantage illégitime). Jej wystąpienie automatycznie ogranicza prawa wierzyciela (domyślnie sępiego funduszu). Może on domagać się od dłużnika spełnienia świadczenia, którego wartość odpowiada cenie zapłaconej przy nabyciu instrumentu dłużnego. Przesłanka nieuzasadnionej korzyści jest przy tym uzależniona od spełnienia dwóch warunków. Pierwszym z nich jest znacząca dysproporcja (fr. disproportion manifeste) pomiędzy ceną nabytego na rynku wtórnym instrumenty dłużnego a jego wartością nominalną. Drugim natomiast wystąpienie jednej z enumeratywnie wskazanych okoliczności. Przykładowo jedną z nich jest systematyczne korzystanie przez wierzyciela z postępowań sądowych w celu uzyskania spłaty odkupionych uprzednio instrumentów.

Ogromną zaletą rozwiązań wdrożonych w drodze rozporządzenia unijnego prawodawcy byłby terytorialny zakres ich obowiązywania. W świetle nowych regulacji sępie fundusze miałyby poważne trudności z dochodzeniem i egzekwowaniem swoich roszczeń na terenie całej UE. Znacząco ułatwiałoby to proces restrukturyzacji zadłużenia państw strefy euro w drodze wykorzystania klauzul wspólnego działania. Problemem przestałby być kształt modyfikacji krzyżowej w CACs oraz interpretacja klauzuli pari passu. Warto przy tym podkreślić, że członkowskie UE emitują skarbowe papiery wartościowe przede wszystkim na rynku krajowym. Odpowiedni popyt na te instrumenty zapewniają inwestorzy z innych państw jednolitego rynku europejskiego, który wykorzystuję możliwość swobodnego transferu kapitału. Emisje zagraniczne, mające charakter uzupełniający, są natomiast plasowane przede wszystkim w innych państwach UE. Sytuacja ta znacząco zwiększałaby skuteczność rozwiązań wdrażanych przez europejskiego prawodawcę. W przyszłości istotnym czynnikiem ryzyka stałoby się natomiast planowane wyjście Wielkiej Brytanii z UE. Niezależnie od ostatecznych uregulowań prawnych w tym zakresie, wydaje się, że istniałaby duża szansa na przyjęcie w tym kraju rozwiązań, które byłyby wzorowane na rozwiązaniach wdrożonych w unijnym porządku prawnym. Wielka Brytania, chcąc pozostać ważnym centrum finansowym dla państw UE, musiałaby uwzględnić ich żywotne interesy. Rozwiązania wymierzone w sępie fundusze zwiększałyby także atrakcyjność tego kraju w oczach poszukujących finansowania zwrotnego państw rozwijających się. Stwierdzenie to ma szczególne znaczenie w świetle niekorzystnego dla związków publicznoprawnych orzecznictwa Sądu Najwyższego Stanów Zjednoczonych, który przyjął szeroką interpretację klauzuli pari passu.

\section{Zakończenie}

Pod wpływem kryzysu zadłużeniowego wdrożono w Unii Europejskiej szereg rozwiązań instytucjonalnych, które mają ułatwiać proces przywracania stabilności fiskalnej państw członkowskich. Część z nich dedykowana jest przy tym wyłącznie krajom wchodzącym w skład strefy euro. Rozwiązania te układają się w logicznie powiązaną całość, noszącą znamiona systemu realizującego jasno określoną funk- 
cję. W tym ujęciu model działalności sępich funduszy rysuje się jako istotne zagrożenie dla skuteczności nowo tworzonego systemu przywracania stabilności fiskalnej. Tego typu podmioty, mając wysoki udział w skarbowych papierach wartościowych krótkich serii, mogą zablokować lub ograniczyć skalę restrukturyzacji zadłużenia publicznego, narażając jednocześnie związki publicznoprawne na długotrwałe procesy sądowe. Sytuacja ta rodzi konieczność podjęcia kroków, które ograniczałyby możliwość działania sępich funduszy w strefie euro - lub szerzej w całej UE. W długookresowej perspektywie rezultat taki można osiągnąć poprzez modyfikację przyjętego modelu CACs lub klauzuli pari passu zawartej w kontraktach emisyjnych skarbowych papierów wartościowych. Wydaje się jednak, że najlepszym i dużo szybszym rozwiązaniem byłaby interwencja unijnego prawodawcy, który mógłby ograniczyć działalność sępich funduszy w drodze rozporządzenia. W tym zakresie punktem wyjścia do prac legislacyjnych mogłyby być przepisy prawa belgijskiego.

\section{Literatura}

Blackman J.I., Mukhi R., 2010, The Evolution of Modern Sovereign Debt Litigation: Vultures, Alter Egos, and Other Legal Fauna, Law and Contemporary Problems, vol. 73:74, fall 2010, s. 47-61.

Das U., Papaioannou M., Trebesch C., 2012, Sovereign Debt Restructurings 1950-2010: Literature Survey, Data, and Stylized Facts, IMF Working Paper no. 12/203, Washington D.C. (7, 2).

De loi de 12 juillet 2015 relative à la lutte contre les activités des fonds vautours.

Deutsche Bundesbank, 2016, Approaches to resolving sovereign debt crises in the euro area, Monthly Report, July, s. 41-62.

Fisch J., 2004, Vultures or Vanguards?: The Role of Litigation in Sovereign Debt Restructuring, Emory Law Journal, vol. 53, s. 1047-1116.

Góralczyk W., 2000, Prawo międzynarodowe publiczne w zarysie, Wydawnictwo Prawnicze PWN, Warszawa.

Hilgers M., 2003, Debtor-States and an International Bankruptcy Court: The IMF Creditor Problem, Chicago Journal of International Law, vol. 4, no. 1, s. 257-264.

IMF, 2012, A Survey of Experiences with Emerging Market Sovereign Debt Restructurings, Policy Papers, Washington D.C.

IMF, 2014, Strengthening the Contractual Framework to Address Collective Action Problems in Sovereign Debt Restructuring, Staff Report, Washington D.C.

Mark W., Weidemaier C., Gulati M., 2012, A People's History of Collective Action Clauses, UNC Legal Studies Research Paper no. 2172302, Chapel Hill.

Mosionek-Schweda M., Panfil P., 2014, Klauzule wspólnego działania w strefie euro [w:] Miemiec W., Sawicka K. (red.), Instytucje prawnofinansowe w warunkach kryzysu gospodarczego, WoltersKluwer, Warszawa, s. 627-637.

Muse-Fisher J., 2014, Starving the Vultures: NML Capital v. Republic of Argentina and Solutions to the Problem of Distressed-Debt Funds, California Law Review, vol. 102, issue 6, s. 1671-1725.

Seavey C., 2006, The Anomalous Lack of an International Bankruptcy Court, Berkeley Journal of International Law, Volume 24, Issue 2, s. 499-520.

Traktat z 2 lutego 2012 r. ustanawiający Europejski Mechanizm Stabilności, http://www.esm.europa. eu/legal-documents/esm-treaty. 